\title{
saki
}

Studi Akuntansi \& Keuangan Indonesia

\section{PENGARUH MANAJEMEN LABA EFISIEN TERHADAP NILAI PERUSAHAAN DENGAN RASIO PROFITABILITAS}

\author{
Dedie Wijaya
}

Sekolah Bisnis dan Ekonomi, Universitas Prasetiya Mulya

Edu I No. 1, Serpong, Jl. BSD Raya Utama, Pagedangan, Tangerang, Banten 15339

\begin{abstract}
The purpose of this research is to estimate whether Efficient Earnings Management will affect the company's value by using Accounting Performance Analysis ratio as a moderating variable. The presence of Earnings Management misleads investors into producing an incorrect fundamental analysis of a company which effects on the company's value. The methodological tools to estimate earnings management are the Jones (1991), Modified Jones (1995), and Kasznik models (1999) which refer to Siregar and Utama's research (2008). This research based on a research toward a company that is listed in Jakarta Stock Exchange from 2000 to 2014. The results of this research are proven that there is a positive correlation between Efficient Earnings Management and Company's Values, therefore the presence of the Efficient Earning Management will increase the value of a company.
\end{abstract}

Keywords: Efficient Earnings Management, Company's Value, Accounting Performance Analysis

Abstrak: Tujuan penelitian ini adalah untuk menilai apakah Manajemen Laba Efisien berdampak terhadap Nilai Perusahaan dengan Rasio Profitabilitas sebagai variabel mediasi. Dengan adanya Manajemen Laba, menyebabkan investor yang menganalisa suatu perusahaan dengan analisa fundamental akan mengalami mislead dan akan berdampak terhadap Nilai Perusahaan. Metode manajemen laba pada penelitian ini menggunakan model Jones (1991), Modified Jones (1995), Kasznik (1999) yang mengacu kepada penelitian Siregar \& Utama (2008). Sampel yang digunakan dalam penelitian ini adalah perusahaan yang terdaftar pada Bursa Efek Indonesia periode 2000 - 2014. Hasil penelitian ini membuktikan bahwa Manajemen Laba Efisien memiliki hubungan positif terhadap Nilai Perusahaan sehingga dengan adanya manajemen laba yang bersifat efisien akan meningkatkan nilai suatu perusahaan.

Kata Kunci : Manajemen Laba Efisien, Nilai Perusahaan, Rasio Profitabilitas

\section{PENDAHULUAN}

Pasar modal adalah komponen penting dalam dunia perusahaan maupun perekonomian. Hal itu karena manfaatnya sebagai media untuk menyerap investasi sebagai upaya perusahaan dalam memperkuat kinerja keuangannya dan sebagai penghubung antara investor dengan perusahaan maupun dengan institusi pemerintah melalui perdagangan instrumen keuangan. Lebih lanjut, pasar modal mendorong investor sebagai pelaku investasi untuk bergantung kepada faktor fundamental dalam membuat keputusan investasi (Suresh, 2013). 


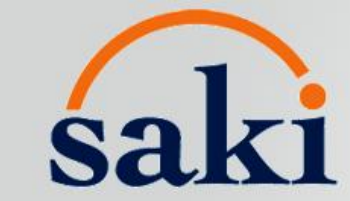

Pada dasarnya, dalam proses pengambilan suatu keputusan investasi, investor mempertimbangkan faktor informasi akuntansi. Informasi akuntansi memiliki nilai relevansi, dengan nilai pasar yang diarahkan untuk menginvestigasi hubungan empiris antara nilai pasar saham dengan nilai yang tertera pada informasi akuntansi yang dimaksudkan untuk menilai manfaat angka - angka dalam penilaian fundamental perusahaan (Puspitaningtyas, 2012).

Fundamental analisis juga merefleksikan kondisi ekonomi suatu perusahaan. Dengan kata lain, melalui analisa fundamental, seorang investor dapat mengetahui kondisi ekonomi atau performa suatu perusahaan (Suresh, 2013). Menurut Suresh (2013) analisa fundamental juga memiliki tujuan untuk memprediksi future price dan future profit.

Kebanyakan investor dalam pengambilan keputusan cenderung melihat suatu laba atau profit dari suatu perusahaan. Menurut Blessing \& Onoja (2015), para investor juga cenderung tertarik untuk melihat profitability dari suatu perusahaan yang tertera dalam financial statement. Melalui financial statement, investor dapat mengetahui posisi keuangan dari suatu perusahaan dimana hal tersebut mengacu pada laba suatu perusahaan (Blessing dan Onoja, 2015). Melalui financial statement, investor juga dapat menilai suatu kinerja perusahaan.

Kinerja perusahaan merupakan sebuah faktor yang penting bagi suatu perusahaan agar dapat terus berkembang dalam menjalankan bisnis mereka. Kinerja perusahaan sendiri biasanya tercermin dalam bentuk laporan keuangan yang biasanya diterbitkan oleh perusahaan guna memberikan informasi kepada investor, kreditor, maupun masyarakat mengenai kondisi perusahaan tersebut. Laporan keuangan yang baik juga dapat memberikan reaksi yang baik pula oleh para pelaku pasar seperti investor maupun kreditor. Menurut OJK (2006), laporan keuangan merupakan syarat wajib bagi setiap perusahaan yang terdaftar di Bursa Efek Indonesia (BEI).

Kebanyakan investor cenderung untuk melihat laporan keuangan dan terfokus pada informasi laba, yang biasanya mengakibatkan pihak manajemen untuk melakukan praktik Manajemen Laba. Praktik Manajemen Laba sendiri dapat berpengaruh pada kualitas informasi laba yang disajikan (Perotti \& Wagenhofer, 2014). Dengan adanya praktik Manajemen Laba, informasi laba yang disajikan dalam sebuah laporan keuangan bukanlah nilai yang sebenarnya sehingga tidak dapat mencerminkan kondisi perusahaan dengan tepat. Hal ini dapat berdampak buruk pada investor dan juga calon investor dalam menyimpulkan informasi yang didapat yang bertujuan untuk melakukan keputusan investasi serta memprediksi return yang diharapkan (Perotti \& Wagenhofer, 2014).

Siregar \& Utama (2008) mengemukakan dalam penelitian mereka bahwa kebanyakan perusahaan yang terdaftar dalam Bursa Efek Indonesia cenderung melakukan Manajemen Laba Efisien. Dalam penelitian tersebut, mereka juga menemukan bahwa perusahaan di Indonesia rata - rata memiliki struktur family ownership yang kemudian berdampak pada penggunaan Manajemen Laba Efisien. Pengertian dari Manajemen Laba Efisien adalah untuk meningkatkan earnings informativeness dalam penyampaian informasi pribadi (Siregar \& Utama, 2008).

Berdasarkan penelitian Siregar \& Utama (2008), dapat disimpulkan bahwa perusahaan indonesia melakukan Manajemen Laba dengan tipe Manajemen Laba Efisien dan memiliki struktur family ownership. Penelitian Nugroho (2009) menjelaskan bahwa investor akan 
bereaksi positif pada saat pengumuman laporan keuangan kepada perusahaan yang melakukan Manajemen Laba yang ditandai dengan return perusahaan yang tinggi.

\section{LANDASAN TEORI}

\section{Teori Agensi (agency theory)}

Teori keagenan berkaitan dengan menyelesaikan dua masalah yang dapat terjadi antara principal dan yaitu: 1) keinginan ataupun tujuan yang berbeda dari kedua belah pihak (prinsipal dan agen), 2) permasalahan dari risk sharing. Prinsipal dan agen memiliki pandangan tersendiri dalam menentukan pilihan resiko yang berujung pada perbedaan cara dalam menyelesaikan masalah yang dihadapi (Jensen dan Meckling, 1976 sebagaimana dikutip dalam Eishenhart, 1989).

Struktur kepemilikan terkonsentrasi mayoritas terjadi di negara Asia termasuk Indonesia. Siregar \& Utama (2008) dalam penelitiannya juga menyebutkan bahwa Indonesia adalah negara yang menganut struktur kepemilikan terkonsentrasi atau memiliki struktur family ownership. Konflik biasanya juga kerap terjadi karena perusahaan yang menggunakan struktur kepemilikan terkonsentrasi meletakkan keluarga mereka dalam manajemen yang mengakibatkan mudahnya dalam mengendalikan kebijakan manajemen dalam mendapatkan keuntungan pribadi bagi manajemen.

\section{Pengertian Manajemen Laba Efisien}

Menurut Siregar \& Utama (2008) Manajemen Laba Efisien bertujuan untuk meningkatkan informasi mengenai laba yang bertujuan untuk mengomunikasikan informasi yang bersifat privat di dalam perusahaan. Manajemen laba yang efisien yang dilakukan oleh manajemen juga bertujuan untuk mengkontrol atau memonitor internal perusahaan sehingga manajer dapat memilih kebijakan akuntansi yang bukan bertujuan untuk memaksimalkan kepentingan pribadi.

Salah satu motivasi dibalik Manajemen Laba ialah karena kebanyakan investor mengandalkan informasi, terutama informasi profitabilitas dari laporan keuangan perusahaan (Nafea et al., 2013). Investor lebih mengandalkan fixed profit daripada varying profit dikarenakan fixed profit dapat menjamin tingginya pembagian dividen (Nafea et al., 2013). Selain itu, profit fluctuation dianggap sebagai faktor penting karena dapat menentukan resiko perusahaan, dan perusahaan yang memiliki smoother profit memiliki resiko yang lebih rendah (Nafea et al., 2013). Kesimpulannya adalah, perusahaan yang memiliki smoother profit, merupakan perusahaan yang lebih menguntungkan dimata investor (Nafea et al., 2013).

Kebanyakan manajer enggan untuk mengumumkan pendapatan perusahaan apabila pendapatan tersebut berada dibawah nilai yang telah diprakirakan karena dapat berpengaruh pada harga saham perusahaan yang akan turun yang akan berujung pada turunnya nilai perusahaan (Ferdawati, 2009). Oleh karena itu, manajer kerap memanipulasi angka-angka pada laporan keuangan yang berdampak pada misleading investor dalam menganalisa kinerja suatu perusahaan (Ferdawati, 2009). 


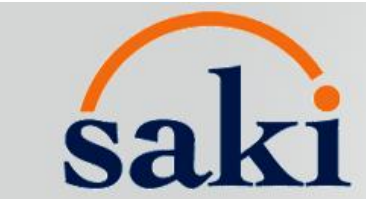

Studi Akuntansi \& Keuangan Indonesia

\section{Pengertian Nilai Perusahaan}

Salah satu tujuan dari perusahaan adalah memaksimalkan nilai perusahaan (Sugiarto, 2011). Nilai perusahaan yang meningkat dapat menunjukkan peningkatan kemakmuran bagi pemegang saham dan juga dapat meningkatkan minat investor untuk menanamkan modalnya dalam suatu perusahaan. Nilai perusahaan yang baik juga tercermin dari harga saham perusahaan yang meningkat (Sugiarto, 2011).

Terdapat beberapa konsep dalam mendeteksi Nilai Perusahaan : nominal value, market value, intrinsic value, book value, dan liquidation value. Namun demikian, disimpulkan bahwa konsep paling baik dalam mendeteksi Nilai Perusahaan adalah melalui intrinsic value walaupun dalam mendeteksi intrinsic value tidaklah gampang dikarenakan diperlukan analisa terhadap variabel signifikan yang dapat menunjukkan profitabilitas dari suatu perusahaan (Christiawan \& Tarin, 2004, sebagaimana dikutip dalam Moeljadi \& Supriyati, 2014). Variabel ini juga berbeda dari satu perusahaan terhadap perusahaan lainnya. Maka dari itu, peneliti biasanya menggunakan market value atau firm's market value dalam mendeteksi Nilai

Perusahaan karena mudahnya dalam mengakses data (Moeljadi \& Supriyati, 2014).

Tingginya Nilai Perusahaan dari suatu perusahaan dapat menarik minat investor untuk menginvestasikan uang mereka terhadap suatu perusahaan (Haruman, 2008, sebagaimana dikutip dalam Moeljadi \& Supriyati, 2014). Para investor cenderung tertarik menginvestasikan uang mereka apabila perusahaan tersebut memiliki return yang baik dan profit yang dapat menjadi keuntungan bagi pemegang saham.

Investor juga cenderung mencari dan juga rela untuk membayar harga tinggi kepada perusahaan yang memiliki untuk menghasilkan pendapatan yang stabil dengan memakai cash flow (Mulford \& Comiskey, 2002) dikarenakan perusahaan tersebut memiliki dampak yang baik bagi share price. Bagi perusahaan sendiri, tingginya share price akan meningkatkan market valuation dan menurunkan cost of capital serta dapat menambahkan keuntungan pribadi (Mulford \& Comiskey, 2002).

Dividen juga merupakan faktor yang dilihat bagi investor sebelum berinvestasi terhadap suatu perusahaan (White, 2015). Bagi kebanyakan investor, dividen berperan penting sebagai salah satu sumber pendapatan dari hasil investasi. Dividen juga merupakan salah satu indikator dalam melihat kesuksesan perusahaan. Dividen didapat dari retained earnings perusahaan, maka dari itu hanya perusahaan yang memiliki profitabilitas yang stabil dan dan konsisten yang dapat membagikan dividennya dengan baik. Ketika perusahaan menampilkan nilai dari historical dividend mereka, investor cenderung tertarik terhadap perusahaan tersebut. Salah satu media untuk mengukur kinerja perusahaan adalah dengan menganalisa laporan keuangan. Namun demikian, menganalisa laporan keuangan bersifat internal. Media lain untuk mengukur kinerja dari perusahaan adalah dengan melihat firm's market value atau kinerja pasar dari perusahaan tersebut. Hal ini bersifat eksternal karena kita berbicara mengenai pasar seperti harga saham, tingkat pengembalian saham, dll. Hal ini memungkinkan semua orang dapat melihat dengan jelas kondisi perusahaan tersebut.

Indikator untuk melihat Nilai Perusahaan dapat diukur dengan menggunakan Price to Book value (PBV) (Marangu \& Jagongo, 2014), Enterprise Value (EV) (Tanmanee et al., 2015), 
Stock Return (Kusumo, 2011), dan Tobin's Q (Sudiyatno \& Puspitasari, 2010).

a) Price to Book Value

Price to Book Value (PBV) merupakan sebuah rasio yang digunakan oleh penasihat investasi, fund managers, dan investor untuk membandingkan market value (market capitalization) perusahaan terhadap book value (shareholder's equity) perusahaan (Marangu \& Jagongo, 2014). Price to Book Value juga merupakan rasio yang menjelaskan berapa banyak saham yang diperjualbelikan dibandingkan dengan book value perusahaan yang merupakan sebuah indikasi berapa banyak pemegang saham membayar aset bersih perusahaan (Marangu \& Jagongo, 2014).

b) Enterprise Value

Tanmanee et al., (2015) mengemukakan bahwa Enterprise Value menjadi faktor penting bagi manajemen dan investor dalam menganalisa sumber keuangan untuk memprediksi future growth perusahaan dan untuk memprediksi return dari investasi mereka.

\section{c) Stock Return}

Menurut Jogiyanto (2000, sebagaimana dikutip dalam Kusumo, 2011) return pada dasarnya dibagi menjadi dua jenis yaitu capital gain/loss dan yield. Capital gain merupakan selisih dari harga investasi sekarang dengan harga periode yang lalu. Jika harga investasi sekarang lebih tinggi dari harga investasi periode lalu berarti terjadi keuntungan modal (capital gain) dan sebaliknya. Yield merupakan presentase penerimaan kas periodik terhadap harga investasi. Keuntungan ini biasanya diterima dalam bentuk kas atau setara dengan kas sehingga dapat diuangkan dengan cepat.

d) Tobin's Q

Tobin's Q adalah indikator untuk mengukur kinerja perusahaan, khususnya tentang nilai perusahaan, yang menunjukkan suatu performa manajemen dalam mengelola aset perusahaan. Nilai Tobin's Q menggambarkan suatu kondisi peluang investasi yang dimiliki perusahaan (Lang, et al, 1989, sebagaimana dikutip dalam Sudiyanto \& Puspitasari, 2010) atau potensi pertumbuhan perusahaan (Tobin \& Brainard, 1968; Tobin, 1969, sebagaimana dikutip dalam Sudiyatno \& Puspitasari, 2010).

\section{Rasio Profitabilitas (Fundamental Analysis)}

Investor juga kerap melakukan kegiatan investasi dengan menggunakan analisa fundamental dan juga analisa teknikal. Namun, banyak penelitian terdahulu yang dalam penelitiannya menggunakan analisa fundamental dengan cara meneliti data-data yang tertera dalam laporan keuangan sebuah perusahaan untuk memperhitungkan dengan harga saham (Artha et al., 2014).

Ketika berbicara tentang kinerja perusahaan, analisa fundamental adalah yang paling umum digunakan adalah mengukur profitability dan return. Rasio finansial ini biasanya dipunlikasikan didalam financial statement perusahaan dan dikenal dengan sebutan Accounting-based Financial Performance (AFP) (Muhammad \& Scrimgeour, 2014). 
Menurut Artha et al., (2014) analisa fundamental adalah suatu studi tentang ekonomi, industri, dan kondisi perusahaan untuk memperhitungkan nilai dari saham perusahaan. Analisis fundamental merupakan metode analisis saham dengan menganalisa data-data atau informasi yang berhubungan dengan kinerja perusahaan, yang umumnya berupa laporan keuangan yang menjadi sumber utama dalam analisa ini dalam menentukan rasio- rasio seperti return on asset (ROA) dan return on equity (ROE) (Muhammad \& Scrimgeour, 2014).

Menurut Palepu et al., (2010, sebagaimana dikutip dalam Muhammad \& Scrimgeour, 2014), return on asset (ROA) menunjukkan jumlah dari profit suatu perusahaan dari setiap satu unit aset. ROA juga menunjukkan bahwa semakin tinggi nilai rasio tersebut, semakin baik pula kinerja dari suatu perusahaan serta menunjukkan tingkat efisiensi manajemen dalam mengelola aset perusahaan untuk mendapatkan pendapatan yang diinginkan.

Sedangkan return on equity (ROE) merupakan indikator dalam menilai kinerja perusahaan karena ROE menunjukkan presentase profit yang didapatkan oleh investasi common stakeholder dari perusahaan. Nilai rasio ROE yang lebih tinggi menunjukan tingkat efisiensi manajemen dalam mengelola modal dan juga berdampak pada return yang baik kepada para investor (Muhammad \& Scrimgeour, 2014).

\section{PENGEMBANGAN HIPOTESIS}

\section{Manajemen Laba Efisien dan Nilai Perusahaan}

Kebanyakan manajer enggan untuk mengumumkan pendapatan perusahaan apabila pendapatan tersebut berada dibawah nilai yang telah diperkirakan karena dapat berpengaruh pada penilaian investor terhadap nilai perusahaan yang berakibat pada turunnya nilai saham (Ferdawati, 2009). Dengan turunnya nilai saham suatu perusahaan, tentu investor juga enggan untuk menginvestasikan uang mereka kepada perusahaan tersebut. Oleh karena itu, manajer biasanya melakukan Manajemen Laba untuk mempertahankan pendapatan perusahaan agar terlihat stabil dan juga terkadang untuk memaksimalkan pendapatan perusahaan agar terlihat baik dimata investor.

Penelitian Siregar \& Utama (2008) menyimpulkan bahwa perusahaan yang terdaftar dalam Bursa Efek Indonesia cenderung melakukan Manajemen Laba Efisien, sehingga dapat disimpulkan bahwa meskipun perusahaan di Indonesia melakukan Manajemen Laba, namun investor percaya bahwa Manajemen Laba tersebut bersifat efficient sehingga investor tetap bereaksi positif.

Berdasarkan penelitian tersebut dapat disimpulkan bahwa investor tetap bereaksi positif terhadap perusahaan yang melakukan Manajemen Laba Efisien dengan tujuan untuk meningkatkan Nilai Perusahaan sehingga investor tertarik kepada perusahaan tersebut. Maka dari itu dapat dirumuskan hipotesis pertama, yaitu:

\section{H1 : Manajemen Laba Efisien yang dilakukan perusahaan yang dinilai positif oleh investor terlihat dari peningkatan Nilai Perusahaan.}




\section{METODE PENELITIAN}

\section{Sumber Data}

Data yang digunakan dalam penelitian ini berupa data sekunder, yaitu data kuantitatif yang diperoleh dari terminal Bloomberg dan Capital IQ Prasetiya Mulya. Data tersebut merupakan data laporan keuangan yang dilakukan oleh perusahaan yang terdaftar di Bursa Efek Indonesia. Berikut variabel yang diambil dari masing - masing terminal :

Tabel 1

Tabel Sumber Data

\begin{tabular}{|l|l|}
\hline \multicolumn{1}{|c|}{ Capital IQ } & Bloomberg \\
\hline Net Income Before Extraordinary & \\
Item & Return on Asset \\
Cash Flow Operation & Return on Equity \\
Tobin's Q & Size \\
Price to Book Value & Leverage \\
Total Enterprise Value & Growth \\
Stock Return & Beta \\
Book Value per Share & \\
Earnings per Share & \\
Market Capitalization & \\
Property, Plant and Equipment & \\
Revenue & \\
Receivable & \\
\hline
\end{tabular}

\section{Populasi dan Sampel}

Populasi penelitian ini adalah data keuangan perusahaan yang terdaftar di Bursa Efek Indonesia (BEI) periode 2000-2014 (498 perusahaan). Sampel penelitian ini merupakan data keuangan perusahaan yang terdaftar di Bursa Efek Indonesia (BEI) periode 2000-2014 namun sudah dikurangi dengan jumlah perusahaan yang memiliki book value negatif, perusahaan yang berada di sektor finansial, dan perusahaan yang memiliki data tidak lengkap.

Metode sampling dilakukan dengan kriteria sebagai berikut :

Tabel 2

Tabel Kriteria Sampel

\begin{tabular}{|l|l|}
\hline Kriteria Sampel Sampel \\
\hline
\end{tabular}




\begin{tabular}{|l|l|}
\hline $\begin{array}{l}\text { Perusahaan yang terdaftar di BEI (2000- } \\
\text { 2014) }\end{array}$ & 498 \\
\hline Less : Perusahaan di Sektor Financial & 88 \\
\hline Less : Book Value negatif & 76 \\
\hline Less : Data tidak lengkap & 39 \\
\hline Total Sampel & 295 \\
\hline
\end{tabular}

*Jumlah Observasi $=295$ Perusahaan $\mathrm{X} 15$ tahun penelitian $=$ 4425 firm's year

a) The Jones Model (Siregar dan Utama, 2008)

$$
T A C C R=\alpha 1\left(\begin{array}{l}
1 \_ \\
\text {At }-1 \\
\ldots \ldots \ldots \ldots(1)
\end{array}\right.
$$

Dimana :

TACCR $=$ Total Akrual $(\mathrm{NIBE}-\mathrm{CFO})$ dibagi dengan total aset tahun sebelumnya $\triangle \mathrm{REV} \quad=$ Pendapatan pada tahun $\mathrm{t}$ dikurangi pendapatan pada

tahun $\mathrm{t}-1$ dibagi dengan total aset tahun sebelumnya

PPE it = Property, plant, and equipment pada tahun t dibagi dengan total aset tahun sebelumnya

$\alpha 1, \alpha 2, \alpha 3=$ Parameter spesifik perusahaan

\section{b) The Modified Jones Model (Siregar dan Utama, 2008)}

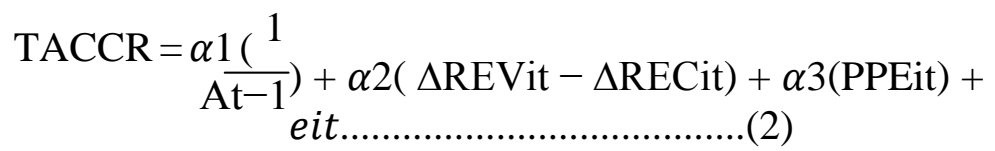

Dimana :

TACCR = Total Akrual (NIBE - CFO) dibagi dengan total aset tahun sebelumnya

$\triangle \mathrm{REVt}=$ Pendapatan pada tahun $\mathrm{t}$ dikurangi pendapatan pada tahun $\mathrm{t}-1$ dibagi dengan total aset tahun sebelumnya

$\triangle \mathrm{RECt}=$ Selisih piutang bersih pada tahun $\mathrm{t}$ dan piutang bersih pada tahun $\mathrm{t}-1$ dibagi dengan total aset tahun sebelumnya

PPE = Property, plant, and equipment pada tahun t dibagi dengan total aset tahun sebelumnya

$\alpha 1, \alpha 2, \alpha 3=$ Parameter spesifik perusahaan 


\section{c) Kazsnik Model (Siregar dan Utama, 2008)}

$$
\mathrm{TACCR}=\alpha 1(1)+\alpha 2(\triangle \mathrm{REVit}-\Delta \mathrm{RECit})+\alpha 3(\mathrm{PPEit})+\alpha 3(\triangle C F O)+
$$

Dimana :

TACCR = Total Akrual (NIBE - CFO) dibagi dengan total aset tahun sebelumnya $\triangle \mathrm{REV} \mathrm{t}=$ Pendapatan pada tahun $\mathrm{t}$ dikurangi pendapatan pada tahun $\mathrm{t}-1$ dibagi dengan total aset tahun sebelumnya

$\triangle \mathrm{RECt}=$ Selisih piutang bersih pada tahun $\mathrm{t}$ dan piutang bersih pada tahun $\mathrm{t}-1$ dibagi dengan total aset tahun sebelumnya

PPEt = Property, plant, and equipment pada tahun t dibagi dengan total aset tahun sebelumnya

$\triangle C F O=$ Selisih arus kas operasi pada tahun t dikurangi tahun sebelumnya dibagi dengan total aset tahun sebelumnya

$\alpha 1, \alpha 2, \alpha 3=$ Parameter spesifik perusahaan

\section{MODEL PENELITIAN}

Model penelitian yang digunakan berupa regresi data panel untuk mengecek hipotesis penelitian. Pada penelitian ini terdapat 3 penelitiaan berdasarkan hipotesis yang telah dibuat. Model pertama digunakan untuk melihat apakah Manajemen Laba memiliki pengaruh terhadap Nilai Perusahaan.

FVit $=\alpha 0+\alpha 1$ EMit $+\alpha 2$ Betait $+\alpha 3 E P S+\alpha 4 M C+\alpha 5$ Bvshare + $\operatorname{cit}(11)$

Keterangan :

$\mathrm{FV}=$ Nilai Perusahaan

$E M$ = Manajemen Laba

Beta $=$ Beta Saham sebagai Variabel Kontrol

EPS = Earning Per Share sebagai Variabel Kontrol

$M C=$ Market Capitalization sebagai Variabel Kontrol

BVShare = Book Value per Share sebagai variabel kontrol

eit = error term

Model Kedua digunakan untuk melihat apakah manajemen laba memiliki pengaruh terhadap Rasio Profitabilitas.

RPit $=\alpha 0+\alpha 1$ EMit $+\alpha 2$ SIZEit $+\alpha 3$ LEVERAGEit $+\alpha 4 G R O W T H i t+$ Eit.

Keterangan :

$\mathrm{RP}=$ Rasio Profitabilitas

$E M=$ Manajemen Laba 
Size $=$ Ukuran Perusahaan sebagai Variabel Kontrol

Leverage $=$ Rasio Hutang sebagai Variabel Kontrol

Growth $=$ Pertumbuhan Perusahaan sebagai Variabel Kontrol

eit $=$ error term

Lalu, model terakhir digunakan untuk melihat apakah Manajemen Laba memilki pengaruh terhadap Nilai Perusahaan melalui Rasio Profitabilitas. Namun, sebelum itu dilakukan fitted value untuk melihat adanya efek mediasi dengan model sebagai berikut :

$$
\text { RPhatit }=\alpha 0+\alpha 1 E M t+\alpha 2 \text { SIZEit }+\alpha 3 L E V E R A G E i t+\alpha 4 G R O W T H+
$$

Eit.

Keterangan :

RPhat = Fitted Value dari rasio profitabilitas

$E M=$ Manajemen Laba

Size $=$ Ukuran Perusahaan sebagai Variabel Kontrol

Leverage $=$ Rasio Hutang sebagai Variabel Kontrol

Growth $=$ Pertumbuhan Perusahaan sebagai Variabel Kontrol

cit = error term

Lalu, model ketiga dalam penelitian ini adalah sebagai berikut:

$F V_{i t}=\alpha 0+\alpha 1 E M t+\alpha 2 R P h a t i t+\alpha 3$ Betait $+\alpha 4 E P S+\alpha 5 M C+\alpha 6$ Bvshare + Eit.

Keterangan :

$\mathrm{FV}=$ Nilai Perusahaan

$E M=$ Manajemen Laba

APAhat $=$ Fitted Value accounting firm

analysis Beta $=$ Beta Saham sebagai Variabel

Kontrol

EPS = Earning Per Share sebagai Variabel Kontrol

$M C=$ Market Capitalization sebagai Variabel Kontrol

BVShare $=$ Book Value per Share sebagai variabel

kontrol $\varepsilon$ it $=$ error term

\section{PEMBAHASAN}

Model utama dalam penelitian ini memakai model Manajemen Laba Kasznik.

Tabel 3

\begin{tabular}{|l|l|l|l|l|}
\hline \multirow{2}{*}{ EM } & \multicolumn{4}{|c|}{ EM to Nilai Perusahaan } \\
\cline { 2 - 5 } & PBV & Stock & TEV & Tobins' \\
\hline Jones & - & - & - & $*$ \\
\cline { 2 - 5 } $\begin{array}{l}\text { Mjones } \\
\text { Kothari }\end{array}$ & - & - & $* *$ & $*$ \\
\cline { 2 - 5 } & - & - & $* * *$ & - \\
\cline { 2 - 5 } & & &
\end{tabular}




\begin{tabular}{|l|l|l|l|l|}
\cline { 2 - 5 } Kasznik & $* * *$ & - & $* *$ & $* * *$ \\
\hline \multicolumn{5}{|c|}{ R-squared } \\
\hline Jones & 0,0351 & 0,0086 & 0,3101 & 0,0431 \\
\cline { 2 - 5 } $\begin{array}{l}\text { Mjones } \\
\text { Kothari } \\
\text { Kasznik }\end{array}$ & 0,0351 & 0,0287 & 0,3099 & 0,0429 \\
\cline { 2 - 5 } & 0,0349 & 0,0083 & 0,3095 & 0,0434 \\
\hline
\end{tabular}

$P B V=$ Price to Book Value; $T E V=$ Total Enterprise

Value; SR = Stock Return; Tobin's $Q=$ Tobin's $Q$

Ratio; Pengujian dilakukan dengan fixed effect

Adapun model yang terbentuk untuk hipotesis pertama berdasarkan tabel diatas adalah :

$$
\begin{aligned}
& F V_{i t}=\alpha 0+\alpha 1 E M i t+\alpha 2 \text { Betait }+\alpha 3 E P S+\alpha 4 M C+\alpha 5 \text { Bvshare }+ \\
& \text { Eit................................. (15) }
\end{aligned}
$$

Peneliti juga melihat hubungan antara Manajemen Laba sebagai variabel independen dengan Rasio Profitabilitas sebagai variabel mediasi. Peneliti juga menemukan bahwa model Kasznik merupakan model yang terbaik dalam meneliti Manajemen Laba ketika dihubungkan dengan Rasio Profitabilitas dengan memiliki nilai $R$-Squared yang lebih tinggi dan nilai signifikansi yang tinggi dibandingkan dengan keempat modellainnya.

\begin{tabular}{|c|c|c|}
\hline \multicolumn{3}{|c|}{ Tabel 4} \\
\hline \multirow[t]{2}{*}{ EM } & \multicolumn{2}{|c|}{$\begin{array}{l}\text { EM to } \\
\text { Accounting }\end{array}$} \\
\hline & ROA & ROE \\
\hline \multirow{4}{*}{$\begin{array}{l}\text { Jones } \\
\text { Mjones } \\
\text { Kothari } \\
\text { Kasznik }\end{array}$} & *** & $* * *$ \\
\hline & $* * *$ & $* * *$ \\
\hline & $* * *$ & $* * *$ \\
\hline & $* * *$ & $* * *$ \\
\hline \multicolumn{3}{|c|}{ R-squared } \\
\hline \multirow{4}{*}{$\begin{array}{l}\text { Jones } \\
\text { Mjones } \\
\text { Kothari } \\
\text { Kasznik }\end{array}$} & 0,2572 & 0,2053 \\
\hline & 0,2531 & 0,1984 \\
\hline & 0,2421 & 0,1864 \\
\hline & 0,4187 & 0,3391 \\
\hline
\end{tabular}

\section{Tabel Pemilihan Model Utama}

Adapun model yang terbentuk untuk hipotesis kedua berdasarkan tabel diatas adalah :

$$
\begin{aligned}
& \text { RPit }=\alpha 0+\alpha 1 \text { EMit }+\alpha 2 \text { SIZEit }+\alpha 3 L E V E R A G E i t+\alpha 4 G R O W T H i t+ \\
& \text { Eit..............................(16) }
\end{aligned}
$$

Kedua tabel diatas menunjukkan nilai Manajemen Laba yang konsisten pada setiap model. 


\section{saki}

Namun, model Kasznik merupakan yang terbaik karena memiliki nilai $R$ Squared yang tinggi. Dimana nilai $R$-Squared merupakan indikator dalam menjelaskan hubungan variabel independen terhadap variabel dependen. Berdasarkan pemilihan model diatas, maka dapat dibuat tabel analisa deskriptif sebagai berikut :

Tabel 5

\begin{tabular}{|c|c|c|c|c|c|c|}
\hline & Minimum & Maximum & Mean & Std.Deviation & Skewness & Kurtosis \\
\hline EM & $(0.780)$ & 0.616 & 0.014 & 0.090 & 0.524 & 2.886 \\
\hline ROA & $(0.050)$ & 0.200 & 0.552 & 0.063 & 0.661 & 2.91 \\
\hline ROE & $(0.200)$ & 0.400 & 0.107 & 0.133 & 0.131 & 3.282 \\
\hline PBV & 0.1 & 31.49 & 4.581 & 7.266 & 1.500 & 2.053 \\
\hline TEV & 6,908 & 16,524 & 13,676 & 1,951 & 0.508 & 1.563 \\
\hline SR & $(0.7)$ & 5.738 & 0.389 & 1.35 & 3.07 & 2.665 \\
\hline Tobins'Q & 0 & 11.38 & 1.471 & 2.928 & 1.472 & 2.601 \\
\hline Size & 8.83 & 19.89 & 14.066 & 1.600 & 3.055 & 1.491 \\
\hline Leverage & 0 & 1.62 & 0.137 & 0.233 & 2.835 & 2.425 \\
\hline Growth & 0.0001 & 4.86 & 0.998 & 1.062 & 2.339 & 3.327 \\
\hline Beta & -10 & 11 & 0.859 & 4.240 & 0.373 & 3.802 \\
\hline EPS & -350 & 772.38 & 91.99 & 192.030 & 0.383 & 3.878 \\
\hline $\begin{array}{c}\text { Mark } \\
\text { et }\end{array}$ & $1,1 \mathrm{E}-08$ & 0,05 & 0,0119 & 0,141838 & 0.760 & 2.191 \\
\hline BV Share & 20 & 4702.99 & 765.84 & 1125.35 & 0.182 & 2.850 \\
\hline
\end{tabular}

$P B V$

Number of observation :4425; ROA = Return on Asset; ROE = Return on Equity;

Tobin's $Q$

$=$ Price to Book Value $;$ LnTEV = Total Enterprise Value $;$ SR = Stock Return;

= Tobin's Q Ratio;); EPS= Earnings per Share;

LnMarket Cap. = Market Capitalization; $B V$ Share $=$

Book Value per Share

\section{PEMBAHASAN UJI HIPOTESIS}

\section{H1 : Manajemen Laba Efisien yang dilakukan perusahaan yang dinilai positif oleh investor terlihat dari peningkatan Nilai Perusahaan}

Seperti yang tertera pada tabel 5 bahwa Manajemen Laba Efisien diuji apakah terdapat pengaruh terhadap Nilai Perusahaan dengan memakai 4 proksi yaitu Price to Book Value (PBV), Stock Return, Total Enterprise Value, dan Tobin's'QRatio.

Dari hasil tabel 6, berdasarkan p-value dari masing-masing proksi, tiga dari empat proksi Nilai Perusahaan memiliki hubungan yang positif dan signifikan terhadap Manajemen Laba Efisien. Tiga proksi ini adalah Price to Book Value (PBV), Total Enterprise Value, dan Tobin's $Q$ Ratio. Dengan hasil yang positif dan signifikan dari ketiga proksi Nilai Perusahaan ini, dapat disimpulkan dengan adanya Manajemen Laba Efisien akan membuat kinerja 
perusahaan terlihat baik di mata investor dan akan mengundang reaksi yang positif dari investor sehingga membuat Nilai Perusahaan perusahaan meningkat. Hasil hipotesis ini selaras dengan penelitian Nugroho (2009) yang menyebutkan bahwa investor akan bereaksi positif pada saat pengumuman laporan keuangan dari perusahaan yang melakukan Manajemen Laba Efisien.

Proksi stock return merupakan satu - satunya proksi yang tidak signifikan dengan prilaku Manajemen Laba Efisien yang dilakukan perusahaan. Manajemen Laba Efisien tidak memiliki hubungan terhadap proksi ini dikarenakan proksi stock return sangat berdasarkan oleh market.

Dalam penelitian ini juga dicoba untuk melakukan analisa rumus dari keempat proksi Nilai Perusahaan dan juga rumus dari model Manajemen Laba yaitu model Kasznik. Setelah melakukan breakdown keempat rumus dari proksi tersebut, ditemukan bahwa proksi stock return adalah satu-satunya proksi yang tidak memiliki variabel accounting didalamnya. Sedangkan ketiga proksi lainnya memiliki unsur variabel accounting. Lalu, ketika dilihat rumus dari model Kasznik, ditemukan pula unsur accounting pada model ini. Sehingga disimpulkan bahwa proksi stock return ketika dihubungkan dengan Manajemen Laba tidak memiliki hubungan karena proksi ini tidak memiliki unsur accounting (fundamental) dan berdasarkan market (teknikal).

Namun terlepas dari unsur itu, tiga dari empat proksi atau model hipotesis pertama adalah positif dan juga signifikan. Maka daripada itu, H1 dapat diterima. 


\section{saki}

Studi Akuntansi \& Keuangan Indonesia

Tabel Hasil Uji Hipotesis Pertama

$F V i t=\alpha 0+\alpha 1 E M i t+\alpha 2$ Betait $+\alpha 3 E P S+\alpha 4 M C+\alpha 5 B v s h a r e+\varepsilon i t$

Tabel 6

\begin{tabular}{|c|c|c|c|c|c|c|c|c|c|}
\hline & \multirow[b]{2}{*}{ Exp.Sig } & \multicolumn{4}{|c|}{ FV (Price to Book Value) } & \multicolumn{4}{|c|}{ FV (Stock Return) } \\
\hline & & Coef & Std. & $\mathbf{P}>\mathbf{t}$ & Sig & Coef & Std. & $\mathbf{P}>$ & Sig \\
\hline \multirow{6}{*}{$\begin{array}{l}\text { EM } \\
\text { bet } \\
\text { a } \\
\text { M } \\
\text { C } \\
\text { Eps } \\
\text { BvSh }\end{array}$} & \multirow{6}{*}{$\begin{array}{l}+ \\
+ \\
+ \\
+ \\
+\end{array}$} & 2,826003 & 1,95505 & 0,000 & $* * *$ & 2,678319 & 6,634226 & 0,19 & - \\
\hline & & $-0,019122$ & 0,03029 & 0,553 & - & $-0,017572$ & 0,019091 & 0,18 & - \\
\hline & & 0,0000 & 0,0000 & 0,000 & $* * *$ & 0,000 & 0,000 & 0,17 & - \\
\hline & & 0,002618 & 0,00074 & 0,000 & $* * *$ & 0,000822 & 0,000226 & 0,00 & $* * *$ \\
\hline & & $-0,001455$ & 0,00035 & 0,000 & $* * *$ & $-0,000129$ & 0,000073 & 0,04 & $* *$ \\
\hline & & 5,251597 & 0,30601 & 0,000 & $* * *$ & 0,194731 & 0,110558 & 0,05 & $*$ \\
\hline \multirow{4}{*}{$\begin{array}{l}\text { Adj } \\
\text { Rsquar } \\
\text { ed }\end{array}$} & & \multirow{2}{*}{\multicolumn{3}{|c|}{$5,57 \%$}} & Prob & \multirow{2}{*}{\multicolumn{3}{|c|}{$0,54 \%$}} & Prob \\
\hline & & & & & 0,000 & & & & 0,008 \\
\hline & & \multicolumn{4}{|c|}{ FV (Total Enterprise Value) } & \multicolumn{4}{|c|}{ FV (Tobins'Q) } \\
\hline & Exp. & Coef & Std. & $\mathbf{P}>\mathbf{t}$ & Sig & Coef & Std. & $\mathbf{P}>$ & Sig \\
\hline \multirow{6}{*}{$\begin{array}{l}\text { EM } \\
\text { bet } \\
\text { a } \\
\text { M } \\
\text { C } \\
\text { Eps } \\
\text { BvSh } \\
\end{array}$} & \multirow{6}{*}{$\begin{array}{l}+ \\
+ \\
+ \\
+ \\
+\end{array}$} & 0,801881 & 0,37812 & 0,035 & $* *$ & 1,629815 & 0,581193 & 0,00 & $* * *$ \\
\hline & & 0,000249 & 0,00064 & 0,7 & - & $-0,001105$ & 0,013387 & 0,00 & $* * *$ \\
\hline & & $-29,65573$ & 4,47076 & 0,000 & $* * *$ & 0,000 & 0,000 & 0,00 & $* * *$ \\
\hline & & 0,000159 & 0,00010 & 0,129 & $*$ & 0,0015 & 0,000334 & 0,00 & $* * *$ \\
\hline & & 0,404271 & 0,57455 & 0,000 & $* * *$ & $-0,000663$ & 0,000123 & 0,00 & $* * *$ \\
\hline & & 11,67254 & 0,27656 & 0,000 & $* * *$ & 1,7335082 & 0,182120 & 0,00 & $* * *$ \\
\hline \multirow{2}{*}{$\begin{array}{l}\text { Adj } \\
\text { Rsquar } \\
\text { ed }\end{array}$} & & \multirow{2}{*}{\multicolumn{3}{|c|}{$30,82 \%$}} & Prob & \multirow{2}{*}{\multicolumn{3}{|c|}{$6,03 \%$}} & Prob \\
\hline & & & & & 0,000 & & & & 0,000 \\
\hline
\end{tabular}

\section{KESIMPULAN}

Dalam penelitian ini berhasil dibuktikan bahwa ada pengaruh positif Manajemen Laba Efisien terhadap Nilai Perusahaan. Hal ini berarti ketika seorang manajer melakukan Manajemen Laba Efisien, maka akan terjadi peningkatan pada Nilai Perusahaan yang diproksikan dengan Price to Book Value, Total Enterprise Value, dan Tobin's Q Ratio. Sehingga dapat dikatakan bhwa manajemen laba yang bersifat efisien akan memiliki pengaruh langsung terhadap nilai perusahaan.

Dengan demikian terdapat pengaruh Manajemen Laba Efisien terhadap Nilai Perusahaan perusahaan dengan melihat pengaruh dari faktor Rasio Profitabilitas. Pada tahap ini juga 


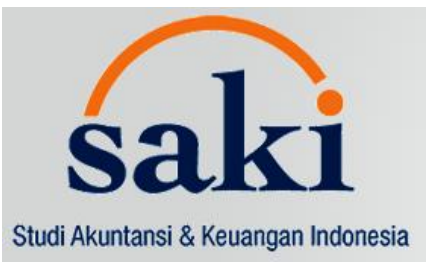

didukung dengan penelitian sebelumnya yaitu Wijaya \& Linawati (2015) yang menyimpulkan dalam penelitian mereka bahwa Return On Asset (ROA) dan Return On Equity (ROE) sebagai pengukuran dari kinerja keuangan memiliki hubungan positif terhadap Tobin's $Q$ Ratio sebagai pengukuran Nilai Perusahaan.

Berdasarkan hal tersebut, dapat dikemukakan bahwa Manajemen Laba secara langsung mempengaruhi Rasio Profitabilitas dari perusahaan. Hal ini tentu dapat berdampak buruk bagi investor karena dapat menyebabkan misleading informasi ketika investor melakukan analisis fundamental terhadap perusahaan. Namun demikian, hasil penelitian ini menjelaskan bahwa reaksi investor tetap positif walupun investor mengetahui adanya Manajemen Laba Efisien yang dilakukan perusahaan. Hal ini dijelaskan dengan hasil yang didapat yaitu ketika Manajemen Laba Efisien memiliki hubungan positif terhadap Nilai Perusahaan melalui mediasi Rasio Profitabilitas.

\section{Daftar Pustaka:}

Arfan, M., \& Antasari, I. (2008). Pengaruh Ukuran, Pertumbuhan, dan Profitabilitas Perusahaan terhadap Koefisien Respon Laba pada Emiten Manufaktur di Bursa Efek Jakarta. Jurnal Telaah \& Riset Akuntansi, 1(1), 50-64.

Artha, D. R., Achsani, N. A., \& Sasongko, H. (2014). Analisis Fundamental, Teknikal, dan Makroekonomi Harga Saham Sektor. Jurnal Manajemen Dan Kewirausahaan, 16(2), 175-184.

Blessing, A. (n.d.). The Role of Financial Statements on Investment Decision Making : A Case Of United Bank for Africa PLC (2004-2013). European Journal of Business Economics and Accounting, 3(2), 12-37.

Departemen Keuangan Republik Indonesia Badan Pengawas Pasar Modal dan Lembaga Keuangan. (2006). Kewajiban Penyampaian Laporan Tahunan Bagi Emiten atau Perusahaan Publik. http://www.martinaberto.co.id/download/Peraturan_Bapepam/X.K.6_Kewajiban_P enyampaian_Laporan_Tahunan_bagi_Emiten_dan_Perusahaan_Publik.pdf

Diniarti, I. (2007). Analisis Pengaruh Earning Per Share, Total Aktiva, Dan Kurs Rupiah Terhadap Risiko Saham Yang Terdaftar Di Bursa Efek Indonesia. Jurnal Ekonomi Akuntansi, 15.

Eisenhardt, K. M. (1989). Agency Theory: An Assessment and Review. Academy of Management Review, 14(1), 57-74.

Ferdawati (2009). Pengaruh Manajemen Laba Real terhadap Nilai Perusahaan. Jurnal Akuntansi \& Manajemen, 4(1), 59-74.

Firdaus, N. (2012). Analisis Pengaruh Struktur Kepemilikian Terhadap Kinerja Perusahaan Berdasarkan Siklus Hidup ( Studi pada Perusahaan Manufaktur IT dan Multimedia yang Terdaftar di Bursa Efek Indonesia Periode 2005-2010). Jakarta.

Gill, A., Biger, N., \& Mand, H. S. (2013). Manajemen Laba, Firm Performance, and the Value of Indian Manufacturing Firms. International Research Journal of finance and Economics, 120-132.

Ghozali, I. (2011). Aplikasi Analisis Multivariate dengan Program IBM SPSS 19. Semarang: 
Badan Penerbit Universitas Diponegoro.Gujarati, D.N. \& D.C. Porter, (2009), "Basic Econometrics", 5th edition, McGraw-Hill, New York, (terjemahan: Mardanugraha, dkk., 2010, Dasardasar Ekonometrika", Salemba Empat).

Gunawan, F. F., Rudiawarni, F. A., Sutanto, A. C.C. (2014). Hubungan antara Financial Distress dengan Manajemen Laba pada Badan Usaha Sektor Manufaktur yang Terdaftar di BEI Periode 2010-2012. Jurnal Ilmiah Mahasiswa Universitas Surabaya, 3(1), 1-18.

Hassan, S. U., Ahmed, A., (2012). Corporate Governance, Manajemen Labaand Financial Performance : A Case of Nigerian Manufacturing Firms. American International Journal of Contemporary Research, 2(7), 214-226.

Healy, P. M., \& Wahlen, J. M. (1999). A Review of the Manajemen Laba Literature and Its Implications for Standard Setting. Accounting Horizons, 13(4), 365-383.

Jagongo, A. O., \& Marangu, K. (2015). Price to Book Value Ratio and Financial Statement Variables (An Empirical Study of Companies Quoted At Nairobi Securities Exchange, Kenya. Global Journal of Commerce \& Management Perspective, 3(6), 50-56.

Kang, S. A., \& Kim, Y. S. (2011). Does Manajemen Laba Amplify the Association between Corporate Governance and Firm Performance? Evidence from Korea. International Business \& Economics Research Journal. 10(2), 53-66.

Kasznik, R. (1999). On the Association between Voluntary Disclosure and Manajemen Laba. Journal of Accounting Research, 57-81.

Kothari, S., Leone, A. J., \& Wasley, C. E. (2005). Performance Matched Discretionary Accrual Measures. Journal of Accounting and Economics, 163-197.

Kusumo, RM. G. I., (2011). Analisis Pengaruh Rasio Keuangan terhadap Return Saham pada Perusahaan Non Bank LQ 45. Universitas Diponegoro.

Moeljadi, \& Supriyati, T. S. (2014). Factors Affecting Firm Value: Theoritical Study on Public Manufacturing Firms in Indonesia. South East Asia Journal of Contemporary Business, Economics, and Law. 5(2), 6-15).

Muhammad, N., \& Scrimgeour, F. (2014). Stock Returns and Fundamentals in the Australian Market. Asian Journal of Finance \& Accounting, 6(1), 271-290.

Mule, R. K., \& Mukras, M. S. (2015). Financial Leverage and Performance of Listed Firms in a Frontier Market: Panel Evidence from Kenya. European Scientific Journal, 11(7), 534-550.

Mulford, C. W., \& Comiskey, E. E. (2002). The Financial Numbers Game : Detecting Creative Accounting Practices. United States: John Wiley \& Sons, Inc.

Nafea, S., Vakilifard, H., \& Fathollahi, J. (2011). A Survey of the Relationship between Income Smoothing and Stock Market Prices and Financial Ratios in Accepted Firms in Tehran Stock Exchange. Journal of Life Science and Biomedicine, 3(2), 135-1399

Nugroho, B. Y. (2009). Reaksi Investor terhadap Manajemen Laba. Jurnal Siasat Bisnis, 13(1), 29-41.

Park, H. M. (2009). Linear Regression Models for Panel Data Using SAS, Stata, LIMDEP, and SPSS. 


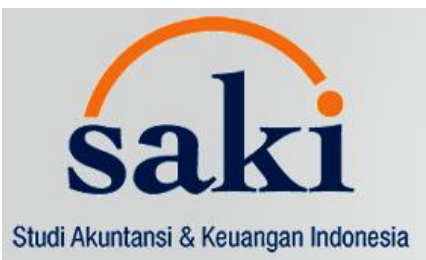

Pernyataan Standar Akuntansi Keuangan. (2009). Penyajian Laporan Keuangan. https://staff.blog.ui.ac.id/martani/files/2011/04/ED-PSAK-1.pdf

Perotti, P., \& Wagenhofer, A. (2014). Earnings Quality Measures and Excess Returns: Earnings Quality Measures and Excess Returns. Journal of Business Finance \& Accounting, 41(5-6), 545-571.

Puspitaningtyas, Z. (2012). Relevansi Nilai Informasi Akuntansi dan Manfaatnya Bagi Investor. Jurnal Ekonomi Dan Keuangan, 16(2), 164-183.

Septiani, N. N. D., \& Supadmi, N. L. (2014). Analisis Pengaruh Beta terhadap Return Saham Periode Sebelum dan Saat Krisis Global. E-Jurnal Akuntansi Universitas Udayana, 7(1), 19-32.

Siregar, S. V., \& Utama, S. (2008). Type of Manajemen Laba and the effect of ownership structure, firm size, and corporate-governance practices: Evidence from Indonesia. The International Journal of Accounting, 43(1), 1-27.

Sitompul, K. (2011). Analisis Pengaruh Faktor-faktor Fundamental Terhadap Harga Saham Perusahaan Real Estate dan Property Yang Terdaftar Di Bursa Efek Indonesia.

Sudiyatno, B., \& Puspitasari, E. (2010). Tobin's $Q$ dan Altman Z-Score sebagai Indikator Pengukuran Kinerja Perusahaan. Jurnal Ilmiah Kajian Akuntansi, 2(1), 921.

Sugiarto, M. (2011). Pengaruh Struktur Kepemilikan dan Kebijakan Dividen Terhadap Nilai Perusahaan dengan Kebijakan Hutang sebagai Intervening. Jurnal Akuntansi Kontemporer, 3(1), 1-25.

Sugiyono. (2010). Metode Penelitian Kuantitatif Kualitatif dan R\&D; CV Alfabeta, Bandung. Suresh. (2013). A Study on Fundamental and Technical Analysis. International Journal of Marketing, Financial Service \& Management Research, 2(5),44-59

Tanmanee, K., Prasertari, W., \& Boonyanet, W. (2015). Corporate Governance, Nominees, Board Size and Enterprise Valuation: Experience from an Emerging Market. Global Journal of Contemporary Research in Accounting, Auditing and Business Ethics, 1(1), 213-231.

White, C. B. (2015, 10 09). Investopedia. Retrieved from http://www.investopedia.com/articles/investing/091015/how-dividends-affectstock-prices.asp

Wijaya, A., \& Linawati, N. (2010). Pengaruh Kinerja Keuangan terhadap Nilai Perusahaan dengan Pengungkapan Corporate Social Responsibility dan Good Corporate Governance sebagai Variabel Pemoderasi (Studi Empiris Pada Perusahaan Manufaktur di Bursa Efek Jakarta. Finesta, 3(1), 46-51. 


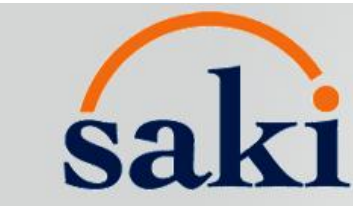

Studi Akuntansi \& Keuangan Indonesia 